\title{
Ultrasonographic Assessment of Knee in Patients with Rheumatoid Arthritis: Is it an Effective Imaging Method for Initial Evaluation?
}

\author{
Romatoid Artritli Hastalarda Ultrasonografik Diz Değerlendirimi: \\ Başlangıç için Etkin bir Görüntüleme Yöntemi midir?
}

\author{
Cüneyt YÜCESOY, ${ }^{1}$ Gülden GENÇ, ${ }^{1}$ Ajda BAL, ${ }^{2}$ Bahri KEYİK, ${ }^{1}$ Emine ÖZTÜRK, ${ }^{1}$ \\ Meriç TÜZÜN, ${ }^{1}$ Aytül ÇAKÇI, ${ }^{2}$ Baki HEKİMOĞLU ${ }^{1}$ \\ ${ }^{1}$ Departments of Radiology, Ankara Dışkapı Yıldırım Beyazıt Training and Research Hospital, Ankara, Turkey; \\ ${ }^{2}$ Departments of Physical Medicine and Rehabilitation, Ankara Dışkapı Yıldırım Beyazıt Training and Research Hospital, Ankara, Turkey
}

\begin{abstract}
Objectives: This study aims to evaluate the effectiveness of ultrasound (US) as an initial imaging method in patients with rheumatoid arthritis.

Patients and methods: Thirty consecutive ( 25 females, 5 males; mean age 55.9 years; range 38 to 74 years) rheumatoid arthritis patients with 30 symptomatic knees were included in the study between November 2006 and August 2008. The intrarticular effusion, synovial proliferation, popliteal cysts and patellarquadriceps tendonitis and weight bearing femoral condylar cartilage thickness and morphology were assessed by US and, within five days, a magnetic resonance imaging (MRI) examination was performed. The results of both examinations were interpreted blindly and compared by two experienced radiologists in their field.
\end{abstract}

Results: In the comparisons of the results of US and MRI examinations, both modalities were mostly concordant. A significant rate of concordance was found between US and MRI results, for joint effusion $(\kappa=0.683, p<0.001)$ synovial proliferation $(\kappa=0.595, \mathrm{p}<0.001)$, popliteal cysts $(\kappa=0.865, \mathrm{p}<0.001)$ and tendonitis $(\kappa=0.889, \mathrm{p}<0.001)$. On the US, the mean medial and lateral femoral condylar cartilage thickness was calculated as $2.1 \mathrm{~mm}$ on both sides, whereas the MRI revealed $1.8 \mathrm{~mm}$ on the medial and $1.9 \mathrm{~mm}$ on the lateral part. In the statistical analysis, the condylar cartilage was significantly thicker on the US than on the MRI $(p<0.001)$. On the other hand, there was a significant correlation between two modalities regarding the cartilage morphology, both on the medial $(\kappa=0.658, p<0.001)$ and the lateral part $(\kappa=0.851, p<0.001)$.

Conclusion: The high correlation rate between the results of US and MRI have shown that in rheumatoid arthritis patients with knee joint involvement, US is an easily accessible and effective alternative method of examination.

Key words: Cartilage; knee; magnetic resonance imaging; rheumatoid arthritis; ultrasound.
Amaç: Bu çalışmada, romatoid artritli hastalarda başlangıç görüntüleme yöntemi olarak ultrasonun (US) etkinliği değerlendirildi.

Hastalar ve yöntemler: Bu çalışmaya Kasım 2006 - Ağustos 2008 tarihleri arasında 30 semptomatik dize sahip 30 ardışık romatoid artrit hastası (25 kadın, 5 erkek; ort. yaş 55.9 yıl; dağılım 38-74 yıl) dahil edildi. Eklem içi efüzyon, sinoviyal proliferasyon, popliteal kistler ve patellar tendonit-kuadriseps tendoniti ve yük taşıyan femoral kondiler kıkırdak kalınlığı ve morfolojisi US ile değerlendirildi ve bunun ardından beş gün içinde bir manyetik rezonans görüntüleme (MRG) incelemesi gerçekleştirildi. Her iki incelemenin sonuçları konularında deneyimli iki radyolog tarafından kör olarak yorumlandı ve karşılaştırıldı.

Bulgular: Ultrason ve MRG incelemelerinin sonuçları karşılaştırıldığında, iki yöntemin büyük oranda uyumlu olduğu gözlemlendi. Ultrason ve MRG sonuçları arasında eklem efüzyonu $(\kappa=0.683, p<0.001)$, sinoviyal proliferasyon $(\kappa=0.595$, $p<0.001)$, popliteal kistler $(\kappa=0.865, p<0.001)$ ve tendonit $(\kappa=0.889, p<0.001)$ açısından anlamlı oranda uyum bulundu. Ortalama femoral kondiler kıkırdak kalınlıkları US'de her iki tarafta $2.1 \mathrm{~mm}$ ölçülürken MRG incelemesinde medialde $1.8 \mathrm{~mm}$ lateralde $1.9 \mathrm{~mm}$ olarak hesaplandı. İstatistiksel analizde kondiler kıkırdak US'de MRG'dekine kıyasla anlamlı şekilde daha kalındı ( $p<0.001)$. Kıkırdak morfolojisi göz önüne alındığında ise hem medial $(\kappa=0.658, p<0.001)$ hem de lateral $(\kappa=0.851, p<0.001)$ kesimde her iki yöntem arasında anlamlı bir uyum saptandı.

Sonuç: Çalışmamızdaki US ve MRG sonuçları arasında tespit edilen yüksek korelasyon oranı diz eklemi tutulumu olan romatoid artritli hastalarda US'nin kolay ulaşılabilir ve etkin bir alternatif inceleme yöntemi olduğunu göstermiştir.

Anahtar sözcükler: Kıkırdak; diz; manyetik rezonans görüntüleme; romatoid artrit; ultrason.

Received: November 29, 2009 Accepted: April 12, 2010

Correspondence: Cüneyt Yücesoy, M.D. Ankara Dışkapı Yıldırım Beyazıt Egitim ve Araştırma Hastanesi, Radyoloji Kliniği, 06110 Dışkapı, Ankara, Turkey. Tel: +90 312 - 5962640 e-mail: yucecun2000@yahoo.com

Presented at the $16^{\text {th }}$ Annual Congress of the European Society of Musculoskeletal Radiology (ESSR) June 12-13, 2009, Genoa, Italy.

(02011 Turkish League Against Rheumatism. All rights reserved. 
Rheumatoid arthritis (RA) is a chronic and a systemic disease affecting approximately 0.5-1\% of the adult population. Early diagnosis and early treatment of RA are mandatory for the prevention of irreversible joint damage and disability. ${ }^{[1-4]}$ The knee is commonly affected in RA, and the diagnosis of synovial inflammation and joint effusion are usually done by clinical examination; however, clinical examination only may lead to delayed diagnosis and treatment. Since the early changes generally begin in soft tissues, ultrasound (US) and magnetic resonance imaging (MRI) seem to be superior to clinical examination, conventional radiography, and computed tomography. ${ }^{[5,6]}$

Magnetic resonance imaging is the best imaging modality for RA and provides multiplanar imaging without ionizing radiation, and it allows for the assessment of all involved structures such as the synovial membrane, effusions, cartilage, bone, ligaments and tendons. Despite the advantages, there are some limitations with this modality. It is time consuming, expensive, and less available. With the recent advances in high-frequency transducers, US has become an important method for the diagnosis of RA and musculoskeletal diseases. Ultrasound is an inexpensive, more accessible, and dynamic imaging modality. Besides, it allows for quick, multiplanar and real time examination of several joints in different body regions in one session. However, US cannot penetrate the bone and is operator-dependent. ${ }^{[3,5-7]}$

Although US has been a widely used modality to diagnose and monitor patients with $\mathrm{RA},{ }^{[3,5,6,8,-15]}$ to the best of our knowledge, there are no studies that have evaluated the use of US and MRI in the description of all the disease components of the knee such as cartilage and soft tissue changes in a single study on adults. Thus, this study aimed to evaluate the effectiveness of US evaluation of the knee joint in RA and its correlation with MRI and to support the present data for validation of the use of US in this area.

\section{PATIENTS AND METHODS}

The ethics committee of the Dışkapı Yıldırım Beyazıt Education and Research Hospital approved this study. Thirty consecutive patients ( 25 females, 5 males; mean age 55.9 years; range 38 to 74 years) with a symptomatic knee affected by rheumatoid arthritis were included in the study between November 2006 and August 2008. Diagnosis was based on the criteria issued by the American College of Rheumatology (ACR), ${ }^{[4]}$ and the
Department of Physical Medicine and Rehabilitation of the same institute referred all the patients. Patients with no clinical evidence of knee involvement were not included in the study.

The sonographic evaluation was conducted using GE Logiq S6 (GE Healthcare, Milwaukee, Wisconsin, USA) with a 7-12 MHz high-frequency linear transducer or Toshiba, Powervision 6000 SSA-370A (Toshiba, Tokyo, Japan) with a 6-11 MHz high-frequency linear transducer by a radiologist who was experienced in musculoskeletal sonography.

The US examination was performed first with the patient in a supine position in which the knee is flexed approximately 20-30 degrees while supported by a pillow, and the transducer was positioned longitudinally above the patella at the level of suprapatellar recess. The total synovial thickness and anteroposterior diameter of the suprapatellar bursa were measured. The synovial proliferation was considered positive when the total synovial thickness was above $3 \mathrm{~mm}$, and the effusion was considered positive when it was $5 \mathrm{~mm}$ or higher (Figure 1a, b). During the longitudinal scan at the level of the suprapatellar recess, special attention was paid not to compress the recess. In the evaluation of the synovial proliferation, any presence of vascularization as a supporting evidence was evaluated with the color mode of the power Doppler US (Figure 2). However, because the study aimed to compare the $B$ mode US findings and MRI findings and no contrast material was used in the MRI evaluations, spectral analyses and/or comparisons could not be made. In the same position, the patellar and quadriceps tendons were examined, and tendonitis was diagnosed if the thickness was increased and blurring and heterogeneous hypoechogenecity were differentiated.

In the second position, the weight bearing medial and lateral femoral condylar cartilage thickness and clarity were evaluated with the knee in maximum flexion. The femoral condylar cartilage was measured on the weight-bearing area approximately $1.5 \mathrm{~cm}$ away from the intercondylar notch (Figure 3). The cartilage morphology was assessed using a scale: 1 for regular-clear (Figure $4 \mathrm{a}, \mathrm{b}$ ) and 0 for irregular, non-clear (Figure 5a, b). Finally, all the patients were evaluated for popliteal cysts with the knee extended in a prone position, and any presence of popliteal cysts was recorded.

The findings of the MRI examination conducted on all the patients within five days were included in 

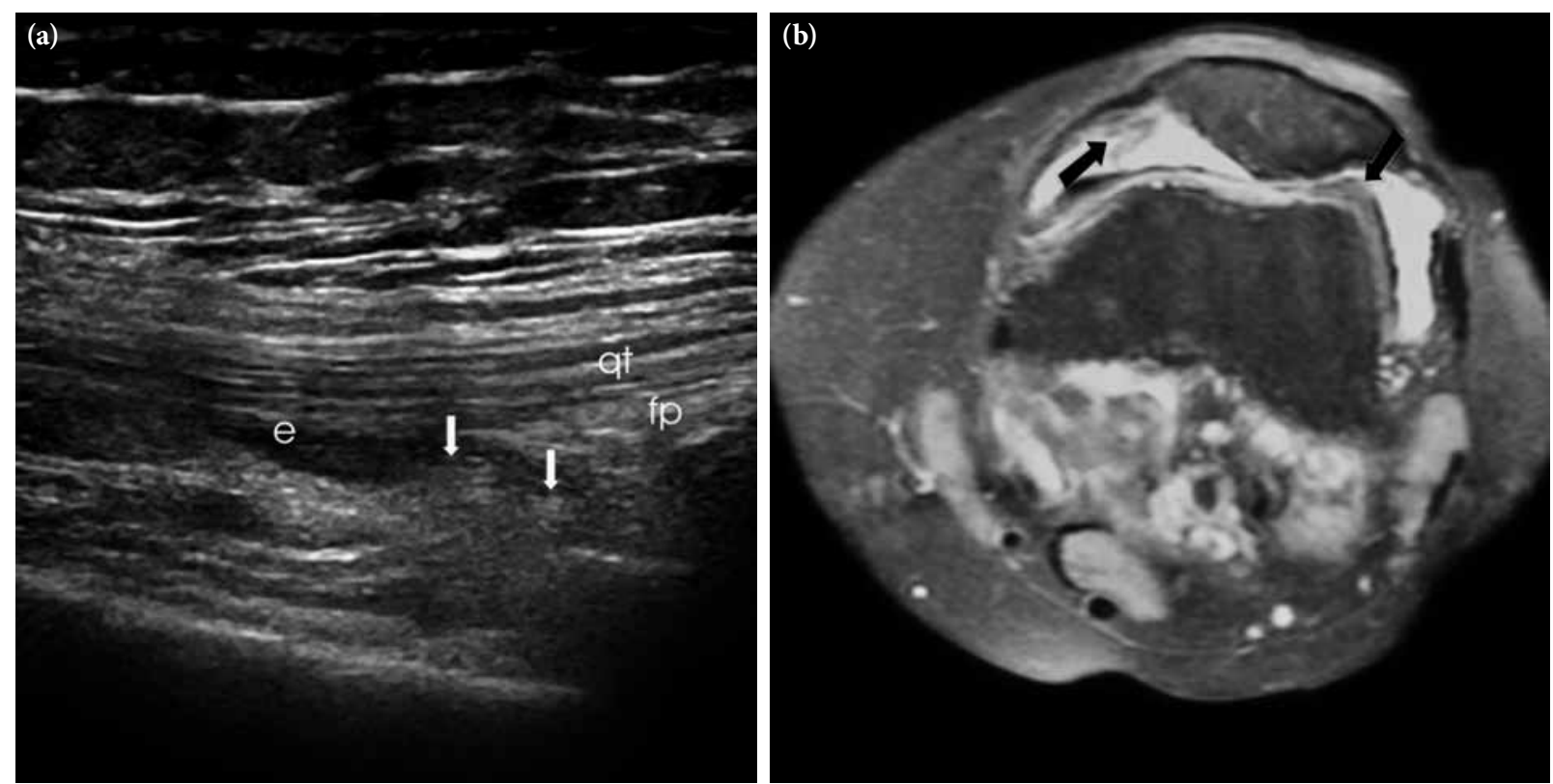

Figure 1. (a) At the suprapatellar recess, marked nodular synovial proliferation is shown on the sagittal plane US (arrows). Note the minimal joint effusion. (b) Synovial proliferation (arrows) and joint effusion on the axial fat saturated T2-weighted images. e: Effusion; qt: Quadriceps tendon fp: Suprapatellar fat pad.

the study. The patients who could not tolerate the examination were excluded from the study. All the analyses were performed on a 1.5 tesla MRI unit (Somatom Vision Plus; Siemens, Erlangen, Germany) using a phased array knee coil. The imaging protocol included spin echo sagittal T1-weighted images (T1WI) (TR 450, TE 12-15, slice thickness $4 \mathrm{~mm}$, matrix $192-256 \times 256$ and field of view $16-18 \mathrm{~cm}$ ), axial and

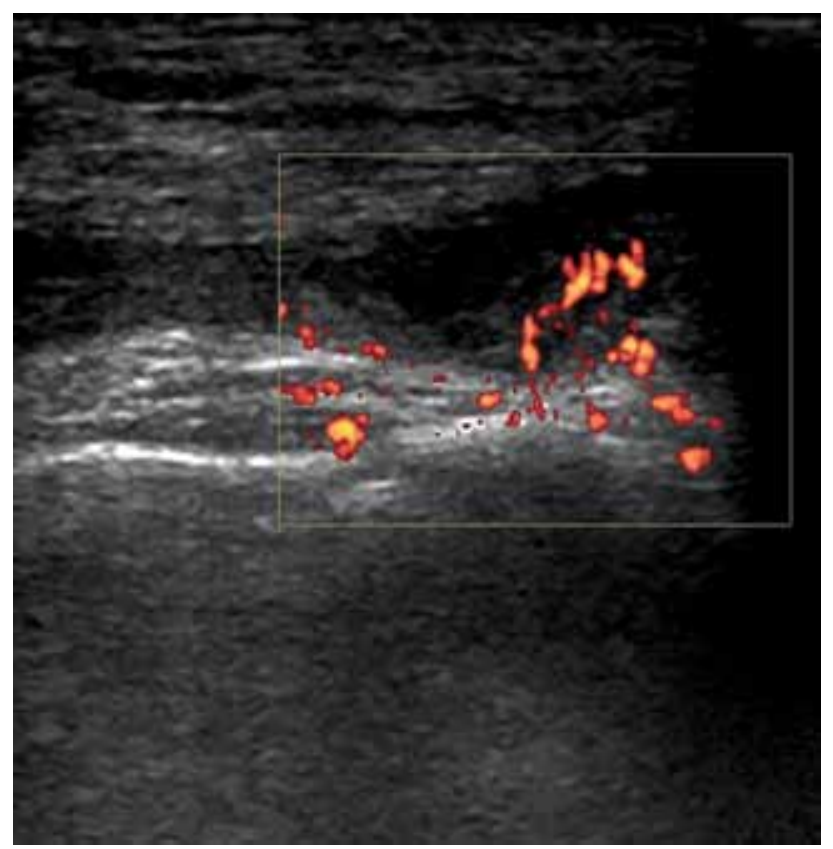

Figure 2. At the suprapatellar recess, synovial proliferation and marked vascularity on the power Doppler ultrasound. sagittal fast spin echo fat saturated proton density (PD) and T2-weighted images (T2WI). (TR 3000, TE $16 / 75$, slice thickness $4 \mathrm{~mm}$, matrix 192-256x256 and field of view $(16-18 \mathrm{~cm})$. For cost efficiency purposes, the sequences were limited, and no contrast materials were used. Magnetic resonance imaging findings were interpreted and reported blindly by a radiologist experienced in musculoskeletal radiology. Effusion and synovial proliferation were assessed on fat saturated $\mathrm{T} 2 \mathrm{WI}$, whereas cartilage thickness and morphology were evaluated both on T2WI and on PD images at the central part of the lateral and medial condyles. The quadriceps-patellar tendons and popliteal cysts were reviewed on both T1WI and T2WI on sagittal and axial images.

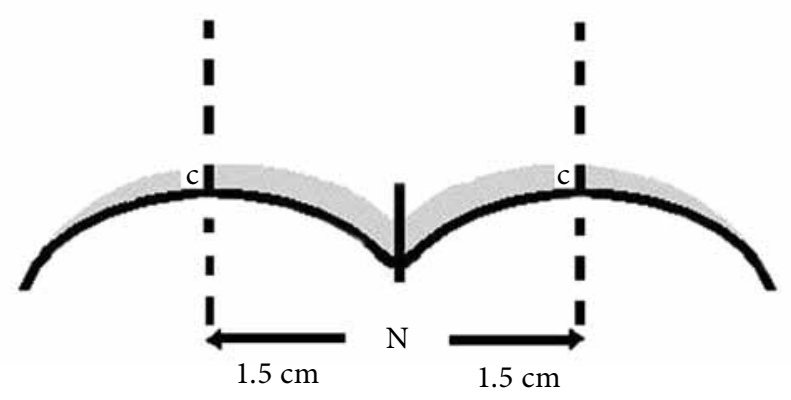

Figure 3. Schematic diagram illustrating the femoral condylar cartilage (gray zone) and femoral intercondylar notch $(\mathrm{N})$. The measurements were done $1.5 \mathrm{~cm}$ away from the midportion of the femoral intercondylar notch. The zones of weight bearing cartilage thickness measured are labeled with (c). 


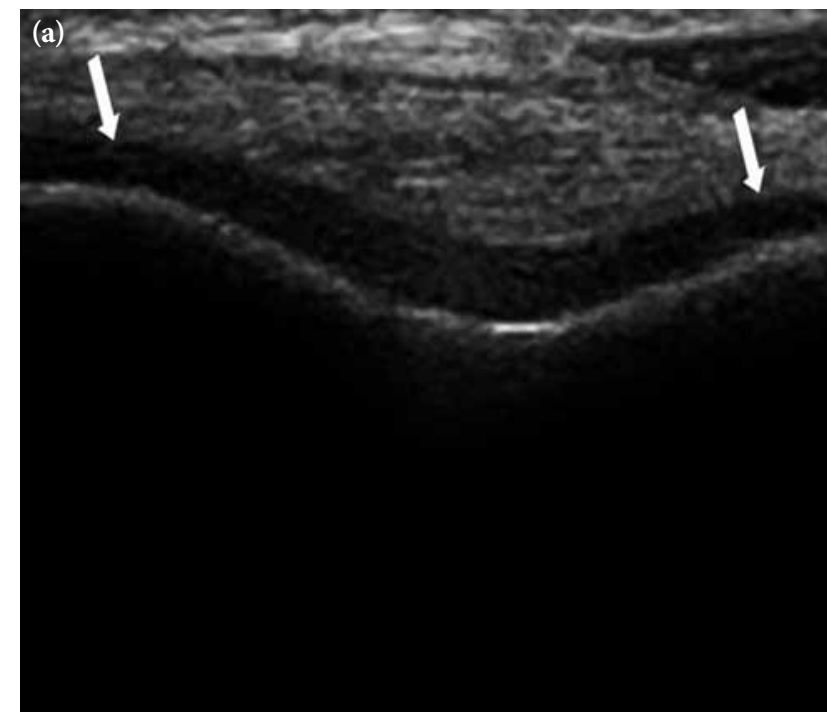

Figure 4. (a) The weight bearing cartilage is clearly demonstrated on the transverse sonogram (arrows). Note that the cartilage on both sides is regular, sharp, and clear. (b) Fat saturated sagittal proton density image on the magnetic resonance imaging; the regular normal cartilage is clearly seen (arrows).

After the US and MRI were interpreted blindly by two experienced radiologists, the data was collected and the statistical analysis was performed by a statistician.

\section{Statistical analysis}

Statistical analysis was performed using Statistical Package SPSS 11.5 version software (SPSS Inc.,

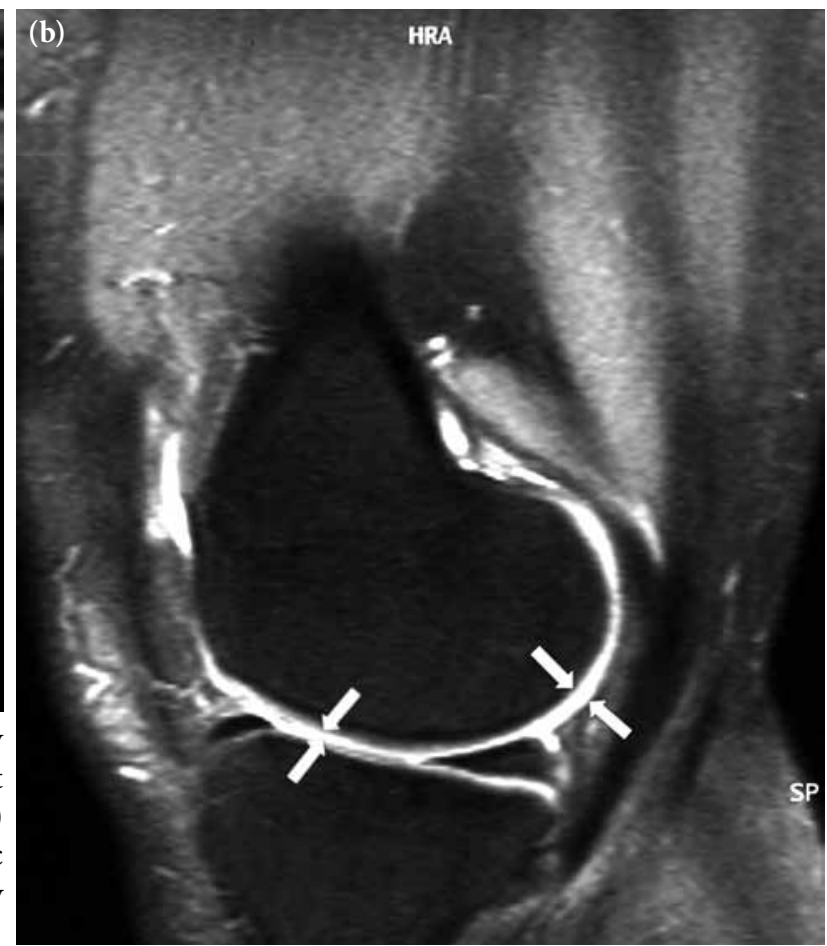

Chicago, Illinois, USA). The distribution of the cartilage thickness (whether distributed normally or not) was determined by using the Shapiro-Wilk test. While continuous variables were expressed as median $\left(25^{\text {th }}-75^{\text {th }}\right)$ percentiles, qualitative data was presented in percentages. The differences between the US and MRI results regarding the cartilage thickness and
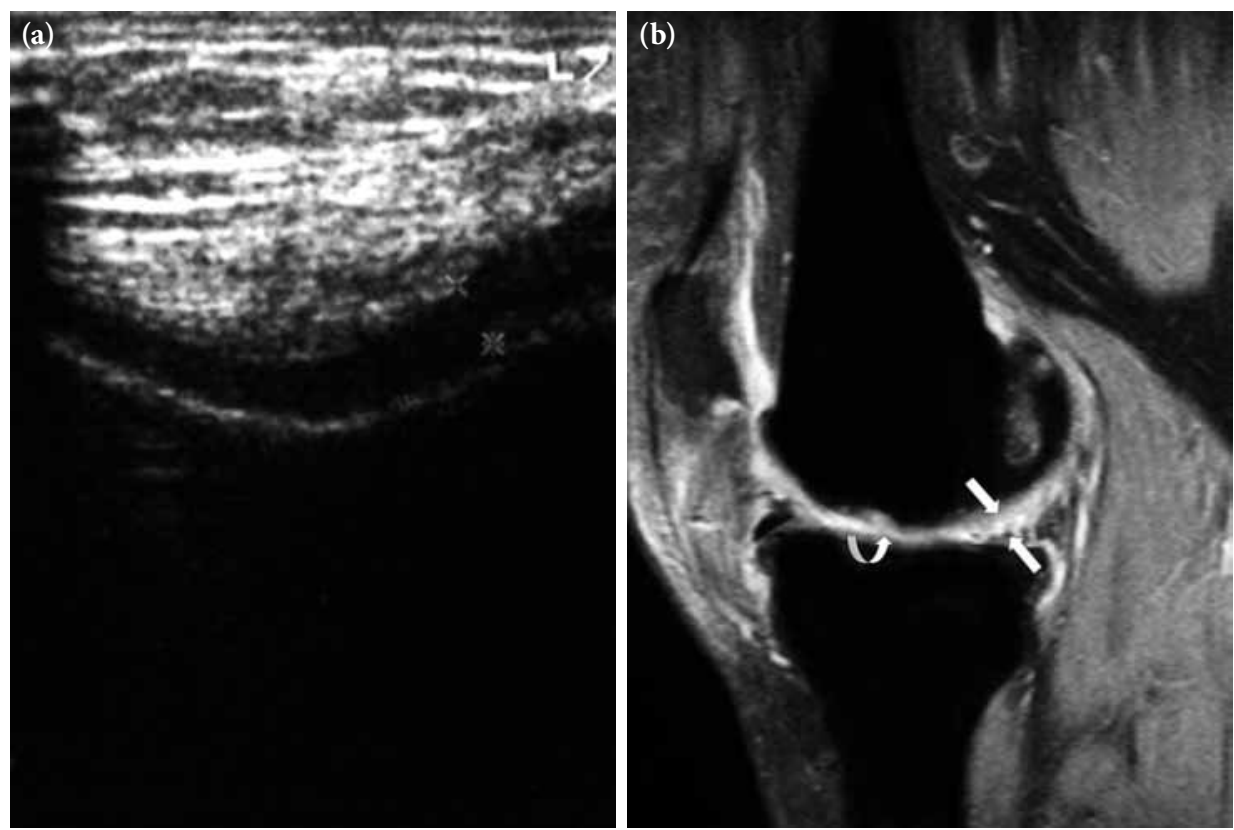

Figure 5. (a) The irregular, non-clear cartilage is demonstrated between the calipers on the ultrasound (b) The irregular, (curved arrow) non-clear (arrows) weight bearing cartilage is demonstrated on the fat saturated sagittal T2-weighted images of the same patient. 
Table 1. Concordance and discordance rates regarding magnetic resonance imaging and ultrasound

\begin{tabular}{|c|c|c|c|c|}
\hline \multirow[t]{3}{*}{ Ultrasound } & \multicolumn{4}{|c|}{ Magnetic resonance imaging } \\
\hline & \multicolumn{2}{|c|}{ Negative } & \multicolumn{2}{|c|}{ Positive } \\
\hline & $\mathrm{n}$ & $\%$ & $\mathrm{n}$ & $\%$ \\
\hline \multicolumn{5}{|c|}{ Synovial proliferation } \\
\hline Negative & 19 & 63.3 & 1 & 3.3 \\
\hline Positive & 4 & 13.3 & 6 & 20.0 \\
\hline \multicolumn{5}{|c|}{ Joint effusion } \\
\hline Negative & 7 & 23.3 & 2 & 6.7 \\
\hline Positive & 2 & 6.7 & 19 & 63.3 \\
\hline \multicolumn{5}{|c|}{ Popliteal cyst } \\
\hline Negative & 12 & 40.0 & 2 & 6.7 \\
\hline Positive & 0 & 0 & 16 & 53.3 \\
\hline \multicolumn{5}{|l|}{ Tendonitis } \\
\hline Negative & 24 & 80.0 & 1 & 3.3 \\
\hline Positive & 0 & 0 & 5 & 16.7 \\
\hline \multicolumn{5}{|c|}{$\begin{array}{l}\text { A statistically significant rate of concordance was found between ultrasound } \\
\text { and magnetic resonance imaging results for synovial proliferation }(\kappa=0.595 \text {, } \\
p<0.001) \text {, joint effusion }(\kappa=0.683, p<0.001) \text {, popliteal cysts }(\kappa=0.865 \text {, } \\
p<0.001) \text { and tendonitis }(\kappa=0.889, p<0.001) .\end{array}$} \\
\hline
\end{tabular}

morphology were evaluated for statistical significance by the Wilcoxon signed rank and McNemar tests, respectively. The Kappa coefficient was calculated to determine the degree of agreement between the US and MRI. A p value less than 0.05 was considered significant.

\section{RESULTS}

In the comparisons of both examination modalities (US and MRI), the results were generally concordant (Table 1).

Of the 30 knees included in the study, on 26 knees, a consensus was reached regarding joint effusion $(\kappa=0.683, \mathrm{p}<0.001)$ as shown by both MRI and US The discordance was observed in four patients. In two patients, US detected minimal effusion, and the presence of physiologic fluid on MRI was reported. In the remaining two patients with discordant US and MRI findings, the MRI detected minimal effusion that was not diagnosed on the US examination.
There was a significant correlation between the MRI and US evaluations of popliteal cyst $(\kappa=0.865$, $\mathrm{p}<0.001)$ and patellar-quadriceps tendonitis $(\kappa=0.889$, $\mathrm{p}<0.001)$. The MRI detected the popliteal cysts in two and tendonitis in one discordant case that was misdiagnosed on the US. The two popliteal cysts that were diagnosed only on the MRI were under $1 \mathrm{~cm}$ in size, and there were subtle changes at the quadriceps tendon that were reported as tendonitis on MRI in one discordant case.

There was also a significant concordance $(\kappa=0.595$, $\mathrm{p}<0.001)$ on synovial proliferation, and a consensus was reached in 25 patients. Unfortunately, for the results of five patients, there was a disagreement because the MRI showed a minimal proliferation in one, which was not noticed on the US, while in the other four cases, proliferation was not seen on the MRI but diagnosed on the US. For these patients, it was speculated that the synovium might have been mistaken for the suprapatellar fat and regarded as proliferation.

The mean medial and lateral femoral condylar cartilage thicknesses on the US were calculated as $2.1 \mathrm{~mm}$ on both sides, whereas MRI revealed $1.8 \mathrm{~mm}$ on the medial and $1.9 \mathrm{~mm}$ on the lateral part. The statistical analysis showed a significant difference in the condylar cartilage on the medial part $(\mathrm{p}=0.003)$. In total consideration, it was thicker $(\mathrm{p}<0.001)$ on US than MRI (Table 2). On the other hand, there was a statistically significant correlation between two modalities regarding the cartilage morphology, both on the medial $(\kappa=0.658, \mathrm{p}<0.001)$ and the lateral part $(\kappa=0.851, \mathrm{p}<0.001$; Table 3$)$.

\section{DISCUSSION}

Rheumatoid arthritis is a chronic progressive and systemic disease of unknown origin characterized by proliferative synovitis resulting in bone erosion, cartilage damage, and joint destruction. ${ }^{[1-4]}$ Even though the diagnosis of RA is based on the

Table 2. Evaluation of the knee cartilage thickness on the ultrasound and magnetic resonance imaging

\begin{tabular}{cccccc}
$\begin{array}{c}\text { Mean } \\
\text { thickness }(\mathrm{mm})\end{array}$ & $\begin{array}{c}\text { Median } \\
\text { thickness }(\mathrm{mm})\end{array}$ & $\begin{array}{c}25^{\text {th }} \text { percentile } \\
\text { thickness }(\mathrm{mm})\end{array}$ & $\begin{array}{c}75^{\text {th }} \text { percentile } \\
\text { thickness }(\mathrm{mm})\end{array}$ & $p$ & $\begin{array}{c}p \\
\text { total } \\
\text { (US vs MRI) }\end{array}$ \\
\hline 2.1 & 2.1 & 1.7 & 2.4 & & \\
1.8 & 1.7 & 1.5 & 2.1 & $\mathrm{p}=0.003^{*}$ & \\
2.1 & 2.1 & 1.7 & 2.5 & & $\mathrm{p}<0.001^{*}$ \\
1.9 & 2.0 & 1.5 & 2.3 & $\mathrm{p}=0.075$ & \\
\hline
\end{tabular}




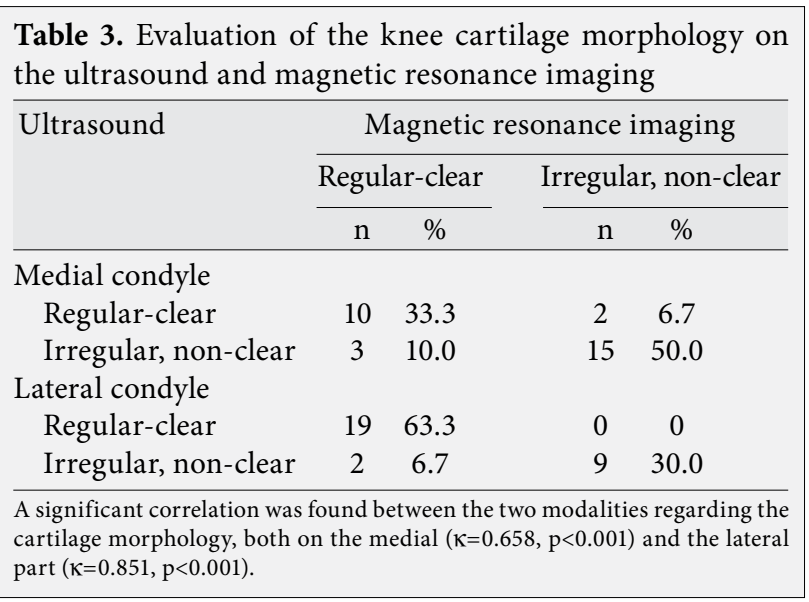

criteria of ACR, there are no clinical, radiologic or immunologic pathognomonic findings to detect the early disease. Conventional radiography has been the mainstay for the diagnosis of joint damage and subsequent follow-up, and it can present the indirect findings of synovial inflammation. Unfortunately, it is not sensitive for the detection of early disease. Magnetic resonance imaging and US seem to be more useful imaging modalities in the evaluation of patients with early RA. Magnetic resonance imaging allows for assessment of all the structures affected by RA; thus, it can be considered the best imaging modality in the diagnosis of RA, particularly in early disease. On the other hand, there are some technical and financial features that limit the routine use of MRI. It is not an appropriate modality for immobile patients or patients with cardiac pacemakers or metallic prosthesis. Current technological advances in high-frequency transducers have made US a highly promising modality in the assessment of RA. ${ }^{[3,5-15]}$ It is a more accessible, cheaper, and more patient-friendly method than MRI, and one of its major advantages is that it can be used as a bedside tool in routine practice.

Literature reveals several reports on the value of US in the assessment of RA..$^{[3,5,8-15]}$ Although there is a comparative study of the knee US and MRI reported in juvenile rheumatoid arthritis, ${ }^{[16]}$ to the best of our knowledge knee US with MRI correlation in evaluating all the components of the disease such as cartilage and soft tissue changes has not been investigated within the same study on adults. Moreover, the concordance between MRI and US in evaluating the cartilage of the knee with osteoarthritis was reported, ${ }^{[17,18]}$ but the weight bearing cartilage morphology and thickness is not well documented in the literature for RA.
In this study, it was demonstrated that the condylar cartilage on the medial part and in general consideration was thicker on the US than on the MRI, and there was a significant statistical difference, respectively $(\mathrm{p}=0.003 ; \mathrm{p}<0.001)$. Sonographic features of the articular cartilage are strongly affected by several factors such as the experience of the operator, the scanning technique, the characteristics of the equipment, the angulation of the transducer and the position of the patient. As Grassi et al. ${ }^{[19]}$ have stated, the visualization of the cartilage interface may also be impaired with the existence of the joint effusion. Similarly, the high rates of joint effusion detected in the present study might have caused the impairment of cartilage interface, leading to thicker cartilage measurements in some patients on the US. The other probable basis for this result can be the interval between the MRI and US. In other words, the probable resolved edema at the cartilage until the MRI examination was performed after US might have also caused significant differences between the results of both modalities. It is obvious that the differentiation of cartilage and effusion is much better in MRI, and that MRI findings are more accurate in the assessment of cartilage thickness when effusion exists. Therefore, it should be stated that special attention must be paid if cartilage thickness is calculated on US in patients with knee effusion.

It is known that a normal femoral condylar cartilage has a clear, smooth and homogeneous hypoechoic appearance parallel to that of the cortical bone on US. Ultrasound has great potential to identify the normal cartilage and allows for differentiation of the abnormal morphology such as loss of clarity, irregularity, and defects on the surface. ${ }^{[7,19]}$ We believe that in the present study, the high concordance rates with MRI have confirmed the accuracy of US in the assessment of cartilage morphology contrary to cartilage measurements.

In the study, it was determined that US facilitated differentiation of the synovial proliferation, joint effusion, popliteal cysts, patellar-quadriceps tendonitis, and cartilage morphology with high concordance rates compared with MRI. Ultrasound, which is an inexpensive, relatively accessible and interactive imaging modality, has been shown to represent the inflammatory and destructive soft tissue changes in patients with RA. ${ }^{[3,5-15]}$ We believe that this result is not surprising, considering the diagnostic value of US in soft tissues, especially in discrimination of effusion and cystic structures. 
The limitations of the present study were the limited number of patients and lack of comparison of the results with the results of a control group. Since the study primarily aimed to investigate the concordance rates between US and MRI rather than comparing the RA findings with a healthy population, no control groups were formed.

Our results with limited patients have pointed out that US is mostly harmonious with MRI findings in the knee joint and is a helpful imaging modality, especially in immobile RA patients and in patients who cannot tolerate MRI. Thus, it has been shown that knee US is a valid and effective initial imaging modality in patients with RA, but the need to be aware of cartilage thickness measurements when effusion exists has also been emphasized.

\section{Declaration of conflicting interests}

The authors declared no conflicts of interest with respect to the authorship and/or publication of this article.

\section{Funding}

The authors received no financial support for the research and/or authorship of this article.

\section{REFERENCES}

1. Bresnihan B. Pathogenesis of joint damage in rheumatoid arthritis. J Rheumatol 1999;26:717-9.

2. Scott DL, Coulton BL, Popert AJ. Long term progression of joint damage in rheumatoid arthritis. Ann Rheum Dis 1986;45:373-8.

3. Sommer OJ, Kladosek A, Weiler V, Czembirek H, Boeck M, Stiskal M. Rheumatoid arthritis: a practical guide to stateof-the-art imaging, image interpretation, and clinical implications. Radiographics 2005;25:381-98.

4. Arnett FC, Edworthy SM, Bloch DA, McShane DJ, Fries JF, Cooper NS, et al. The American Rheumatism Association 1987 revised criteria for the classification of rheumatoid arthritis. Arthritis Rheum 1988;31:315-24.

5. Østergaard M, Ejbjerg B, Szkudlarek M. Imaging in early rheumatoid arthritis: roles of magnetic resonance imaging, ultrasonography, conventional radiography and computed tomography. Best Pract Res Clin Rheumatol 2005;19:91-116.
6. Østergaard M, Pedersen SJ, Døhn UM. Imaging in rheumatoid arthritis-status and recent advances for magnetic resonance imaging, ultrasonography, computed tomography and conventional radiography. Best Pract Res Clin Rheumatol 2008;22:1019-44.

7. Friedman L, Finlay K, Jurriaans E. Ultrasound of the knee. Skeletal Radiol 2001;30:361-77.

8. Farrant JM, O'Connor PJ, Grainger AJ. Advanced imaging in rheumatoid arthritis. Part 1: synovitis. Skeletal Radiol 2007;36:269-79.

9. Farrant JM, Grainger AJ, O'Connor PJ. Advanced imaging in rheumatoid arthritis: part 2: erosions. Skeletal Radiol 2007;36:381-9.

10. Boutry N, Morel M, Flipo RM, Demondion X, Cotten A. Early rheumatoid arthritis: a review of MRI and sonographic findings. AJR Am J Roentgenol 2007;189:1502-9.

11. Brown AK; Medscape. Using ultrasonography to facilitate best practice in diagnosis and management of RA. Nat Rev Rheumatol 2009;5:698-706.

12. Østergaard M, Szkudlarek M. Ultrasonography: a valid method for assessing rheumatoid arthritis? Arthritis Rheum 2005;52:681-6.

13. Østergaard M, Wiell C. Ultrasonography in rheumatoid arthritis: a very promising method still needing more validation. Curr Opin Rheumatol 2004;16:223-30.

14. Kane D, Balint PV, Sturrock RD. Ultrasonography is superior to clinical examination in the detection and localization of knee joint effusion in rheumatoid arthritis. J Rheumatol 2003;30:966-71.

15. Frediani B, Falsetti P, Storri L, Allegri A, Bisogno S, Baldi F, et al. Ultrasound and clinical evaluation of quadricipital tendon enthesitis in patients with psoriatic arthritis and rheumatoid arthritis. Clin Rheumatol 2002;21:203-6.

16. El-Miedany YM, Housny IH, Mansour HM, Mourad HG, Mehanna AM, Megeed MA. Ultrasound versus MRI in the evaluation of juvenile idiopathic arthritis of the knee. Joint Bone Spine 2001;68:222-30.

17. Ostergaard M, Court-Payen M, Gideon P, Wieslander S, Cortsen M, Lorenzen I, et al. Ultrasonography in arthritis of the knee. A comparison with MR imaging. Acta Radiol 1995;36:19-26.

18. Tarhan S, Unlu Z. Magnetic resonance imaging and ultrasonographic evaluation of the patients with knee osteoarthritis: a comparative study. Clin Rheumatol 2003;22:181-8.

19. Grassi W, Lamanna G, Farina A, Cervini C. Sonographic imaging of normal and osteoarthritic cartilage. Semin Arthritis Rheum 1999;28:398-403. 